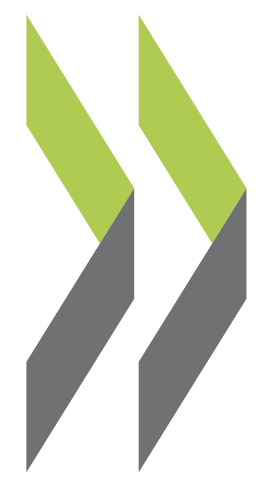

OECD Economics Department Working Papers No. 1678

The economic costs

of restricting international
Elena Rusticelli,

David Turner 


\section{ECONOMICS DEPARTMENT}

\section{THE ECONOMIC COSTS OF RESTRICTING INTERNATIONAL MOBILITY}

\section{ECONOMICS DEPARTMENT WORKING PAPERS No. 1678}

By Elena Rusticelli and David Turner

OECD Working Papers should not be reported as representing the official views of the OECD or its member countries. The opinions expressed and arguments employed are those of the author(s).

Authorised for publication by Luiz de Mello, Director, Policy Studies Branch, Economics Department.

All Economics Department Working Papers are available at www.oecd.org/eco/workingpapers. 
OECD Working Papers should not be reported as representing the official views of the OECD or of its member countries. The opinions expressed and arguments employed are those of the author(s).

Working Papers describe preliminary results or research in progress by the author(s) and are published to stimulate discussion on a broad range of issues on which the OECD works.

Comments on Working Papers are welcomed, and may be sent to OECD Economics Department, 2 rue André Pascal, 75775 Paris Cedex 16, France, or by e-mail to eco.contact@oecd.org.

All Economics Department Working Papers are available at www.oecd.org/eco/workingpapers

This document and any map included herein are without prejudice to the status of or sovereignty over any territory, to the delimitation of international frontiers and boundaries and to the name of any territory, city or area.

The statistical data for Israel are supplied by and under the responsibility of the relevant Israeli authorities. The use of such data by the OECD is without prejudice to the status of the Golan Heights, East Jerusalem and Israeli settlements in the West Bank under the terms of international law.

\section{(c) OECD (2021)}

You can copy, download or print OECD content for your own use, and you can include excerpts from OECD publications, databases and multimedia products in your own documents, presentations, blogs, websites and teaching materials, provided that suitable acknowledgment of OECD as source and copyright owner is given. Requests for commercial use and translation rights should be submitted to PubRights@oecd.org 


\section{ABSTRACT/RESUMÉ}

\section{The economic costs of restricting international mobility}

COVID-19 related travel restrictions, including complete border closures, have been one of the first containment measures to be implemented by many countries and have been continuously adjusted according to the epidemiological situation in departure and destination countries. Despite some easing since mid-2020, the level of such restrictions remain high, especially in Europe and North America. The economic costs of restrictions on international travel are apparent in those sectors most directly impacted, as documented here. However, given their important interlinkages, a uniquely sectoral focus is likely to underestimate the broader macroeconomic costs, which are also assessed, albeit with less precision. The importance of these linkages is borne out by the fact that those OECD countries with the largest travel and tourism sectors -- such as Greece, Iceland, Portugal, Mexico and Spain -- are among those that have experienced the largest falls in GDP in 2020 . Indeed, the pre-crisis size of the travel and tourism sector is found to better explain cross-country differences in GDP growth in 2020, than exposure to any of the other sectors considered most vulnerable to COVID-19, or the average stringency of wider country lockdown measures during 2020. These estimates serve as a means to gauge the potential economic benefits of a rapid return to more normal travel arrangements facilitated by the implementation and agreements around testing and vaccination protocols.

Keywords: Restrictions to international mobility, macroeconomic costs, COVID-19.

JEL codes: F2, F5, J6, R4, Z3.

$* * * * *$

\section{Le coût économique des restrictions sur les déplacements internationaux}

Les restrictions des déplacements internationaux liées au COVID-19, y compris la fermeture complète des frontières, ont été l'une des premières mesures de confinement à être mises en œuvre par de nombreux pays et ont été continuellement ajustées en fonction de la situation épidémiologique dans les pays de départ et de destination. Malgré un certain assouplissement depuis mi-2020, le niveau de ces restrictions reste élevé, notamment en Europe et en Amérique du Nord. Le coût économique des restrictions sur les déplacements internationaux est plus important dans les secteurs les plus directement touchés, comme le montre ce document de travail. Cependant, étant donnée l'importance des interconnexions entre les secteurs, une approche secteur par secteur risque de sous-estimer le coût macroéconomique global, qui est donc évalué par ailleurs, bien qu'avec une précision moindre. L'importance de ces liens est confirmée par le fait que les pays de l'OCDE où le tourisme est le plus important - comme la Grèce, I'Islande, le Portugal, le Mexique et l'Espagne - sont parmi ceux qui ont connu les plus fortes baisses de PIB en 2020. En effet, la taille du secteur touristique avant la crise est un critère qui explique davantage les différences de croissance du PIB observées entre les pays en 2020, que celle des autres secteurs considérés comme les plus vulnérables au COVID-19, ou bien encore que la rigueur moyenne des mesures de confinement du pays en 2020. Ces estimations permette d'évaluer les avantages économiques potentiels d'un retour à la normale rapide des conditions de déplacement, facilité par la mise en œuvre de protocoles de test et de vaccination ainsi que par l'établissement de normes internationales en la matière.

Mots clés: Restrictions sur les déplacements internationaux, coûts macroéconomiques, COVID-19.

Codes JEL: F2, F5, J6, R4, Z3. 


\section{Table of contents}

The economic costs of restricting international mobility 5

1. Introduction 5

2.1. Tourism

2.2. Airline industry 8

2.3. Other transport sectors 9

2.4. Further education 10

2.5. Labour migration 10

3. Broader macroeconomic impacts 11

Tables

Table 1. Economic impact from COVID-19 on the Travel and Tourism sector in 2020

Figures

Figure 1. Travel restrictions are being continuously adjusted over time but remain elevated 6

Figure 2. Millions jobs were lost across the OECD tourism industry in $2020 \quad 8$

Figure 3. The recovery in air travel is stalling after a complete collapse 9

Figure 4. Cruise operations have collapsed 9

Figure 5. OECD countries most exposed to travel and tourism suffered greater falls in services exports and GDP 12

Figure 6. OECD countries suffered a large contraction in travel and tourism GDP 13 


\title{
The economic costs of restricting international mobility
}

\author{
Elena Rusticelli and David Turner ${ }^{1}$
}

\section{Introduction}

1. Restrictions on international travel associated with COVID-19 have led to an unprecedented collapse in the number of international travellers with devastating implications for particular sectors, most notably travel and tourism, and on a scale sufficient to have serious adverse macroeconomic effects. While restricting international travel has been an important policy response to slowing the spread of the virus, an appreciation of the associated economic costs provides the motivation to develop a multilateral and multidisciplinary framework for a return to safe international mobility. This note is one of several that contribute to a proposal for a draft blueprint (OECD, 2021a), which aims to underpin discussions on common approaches to testing procedures with a view to enhancing trust in international travel while vaccination programmes are rolled out (OECD, 2020a).

2. COVID-19 related travel restrictions, including complete border closures, have been one of the first containment measures to be implemented by many countries and continuously adjusted according to the epidemiological situation in departure and destination countries. Since their introduction, very few countries have completely lifted such restrictions, others have eased travel limitations to international tourism but have introduced new procedures, like testing upon arrival, and most continue in keeping their borders partially or completely closed (Figure 1, panel A and B). Despite some easing since mid-2020, the level of such restrictions remain high, especially in Europe and North America (Figure 1, panels B and C). As of end-May, nearly $65 \%$ of European countries have still their borders closed or bans on travels to and from high-risk destinations. In the United States and Canada, all air passengers entering the country are currently required to present a negative COVID-19 test before boarding.

3. The economic costs of restrictions on international travel are apparent in those sectors most directly impacted, as discussed in section 2. However, given their important interlinkages, a uniquely sectoral focus is likely to underestimate the broader macroeconomic costs, which are assessed, albeit with less precision, in section 3 . These estimates serve as a means to gauge the potential economic benefits of a rapid return to more normal travel arrangements facilitated by the implementation and agreements around testing and vaccination protocols.

\footnotetext{
${ }^{1}$ The authors are members of the Macroeconomic Analysis Division of the OECD Economics Department. This work summarises inputs from a number of OECD Directorates, namely: the Economics Department; International Transport Forum, Trade and Agriculture Directorate; and the Centre for Entrepreneurship, SMEs, Regions and Cities. The authors would also like to acknowledge helpful comments on earlier drafts from Luiz de Mello and Vincent Koen as well as invaluable assistance in document preparation from Veronica Humi.
} 
Figure 1. Travel restrictions are being continuously adjusted over time but remain elevated

A. Share of countries with different forms of travel restrictions (\% of all countries)

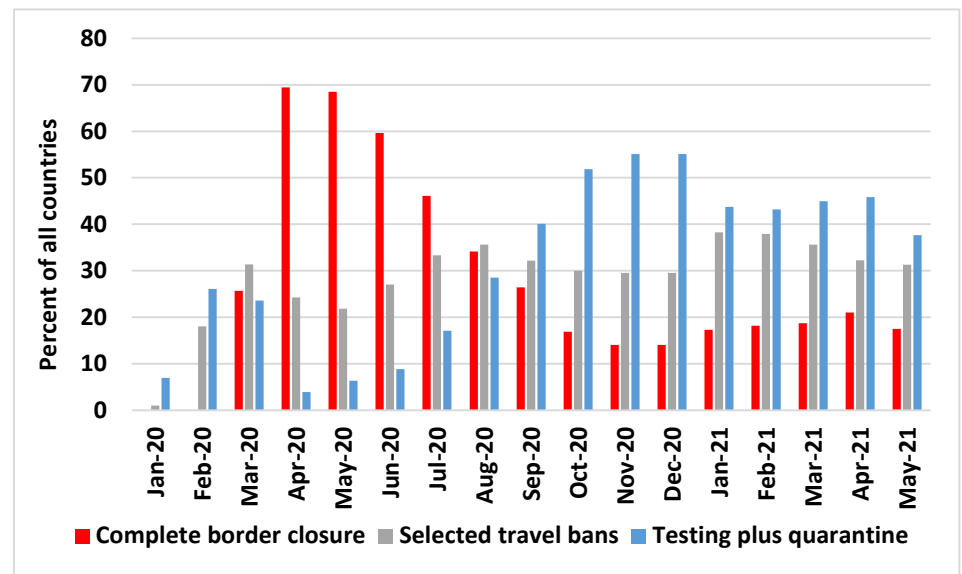

B. Regional international travel restrictions in April-May 2020 and April-May 2021 (\% of population covered)

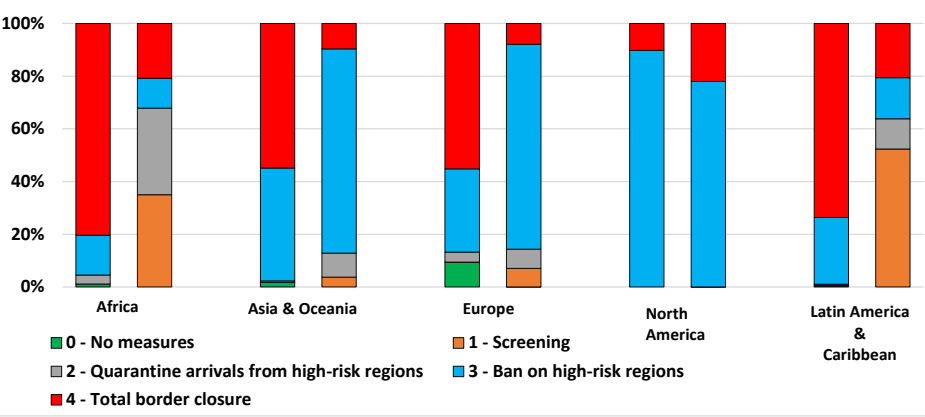

C. Index of overall stringency of restrictions on international travel

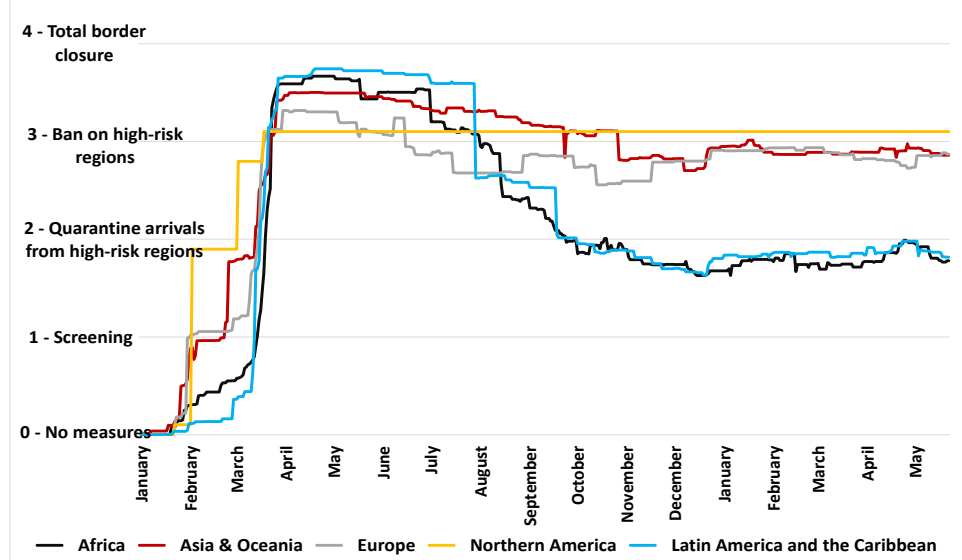

Note: In Panel A, measures referring to screening (category 1 in the stringency index) and quarantine arrivals (category 2 in the stringency index) have been regrouped in one unique category "Testing plus quarantine". In Panel B, the first bar in each pairing shows the average of April-May 2020, which was a peak for restrictions in many regions, and the second bar shows the average for April-May 2021. In Panel C, indices are constructed by weighting together individual country indices using population data.

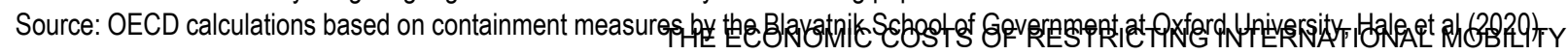
Unclassified 


\section{Sector-specific effects}

4. Restrictions on international mobility have had a dramatic impact on some particular sectors, most notably tourism, but also with massive effects on certain transport sectors such as airlines, and other sectors such as further education, as discussed below.

\subsection{Tourism}

5. OECD estimates international tourism ${ }^{2}$ fell by around $80 \%$ in 2020 (OECD, 2020a). Latest UN World Tourism Organization (UNWTO) estimates point to a 70\% decline year-on-year in travel demand for the whole 2020, with a loss in tourism export revenues, already between January and October, ten times the loss recorded in 2009 amid the global financial crisis (UNWTO, 2020). UNWTO has also expressed fears that any recovery for the sector could be delayed, with pre-crisis levels not achieved before 2023.

6. This is having very tangible economic and social consequences for many people, places and businesses, as well as the wider economy. Tourism generates foreign exchange, supports jobs and businesses, drives regional development and underpins local communities. Before the pandemic, the sector directly contributed about $10 \%$ to global GDP, around 1 in 10 jobs (more than 300 millions), and $27 \%$ of global services exports. However, these shares are much higher for several OECD countries, where tourism is a major driver of economic activities, such as France (8.5\% of GDP), Greece (20.8\%), Iceland (22.8\%), Mexico (15.5\%), Portugal (16.5\%) and Spain (14.3\%).

7. The crisis is putting millions of jobs in the tourism sector at risk. Tourism is highly labour-intensive and provides a high volume of jobs for low-skilled workers, together with higher-skilled jobs. According to the International Labour Organization (ILO), the accommodation and food services subsectors alone globally provide employment for 144 million workers, about $30 \%$ of which are employed in small tourism businesses with fewer than ten employees (ILO, 2020). The scale of job losses is not yet apparent, as government support has protected workers from the full impact of the pandemic. Excluding supported jobs still recorded as employment by national authorities, the World Travel and Tourism Council (WTTC) estimates that up to 61.6 million jobs were lost globally in 2020 (Table 1). Job losses were the largest in the United States (Figure 2), where the travel industry shrank by about 5.6 million of jobs, making up $65 \%$ of all American jobs lost due to the COVID-19 pandemic (U.S. Travel Association, 2021). The European Commission's Joint Research Centre forecasts that between 6.6 and 11.7 million jobs in businesses operating and/or dependent on tourism-related activities are at risk in the European Union, representing between $3.2 \%$ and $5.6 \%$ of the total active population (European Commission Joint Research Centre, 2020).

Table 1. Economic impact from COVID-19 on the Travel and Tourism sector in 2020

\begin{tabular}{l|c|c|c|c|c|c|c|c}
\hline & Global & Europe & Asia-Pacific & $\begin{array}{c}\text { North } \\
\text { America }\end{array}$ & $\begin{array}{c}\text { Latin } \\
\text { America }\end{array}$ & Caribbean & Africa & Middle East \\
\hline Jobs lost (millions) & $61.6(-18.5 \%)$ & $3.6(-9.3 \%)$ & $34.1(-18.4 \%)$ & $7.1(-27.9 \%)$ & $4(-23.4 \%)$ & $0.7(-24.7 \%)$ & $7.2(-29.3 \%)$ & $1.2(-17.4 \%)$ \\
\hline & & & & & & & & \\
\hline GDP loss (USD bn) & $4,498(-49.1 \%)$ & $1,126(-51.3 \%)$ & $1,645(-53.7 \%)$ & $910(-42.2 \%)$ & $110(-41.1 \%)$ & $34(-58 \%)$ & $83(-49.2 \%)$ & $138(-51.1 \%)$ \\
\hline
\end{tabular}

Note: Numbers reported in brackets represent percentage changes from pre-COVID trends for the year 2019.

Source: World Travel and Tourism Council, March 2021 Report.

\footnotetext{
2 International tourism refers to tourism that crosses national borders for tourism purposes (leisure, business, etc.). OECD estimates are based on international tourism arrivals in the OECD area.
} 
Figure 2. Millions jobs were lost across the OECD tourism industry in 2020

Percentage change in total travel and tourism jobs in 2020 compared to 2019

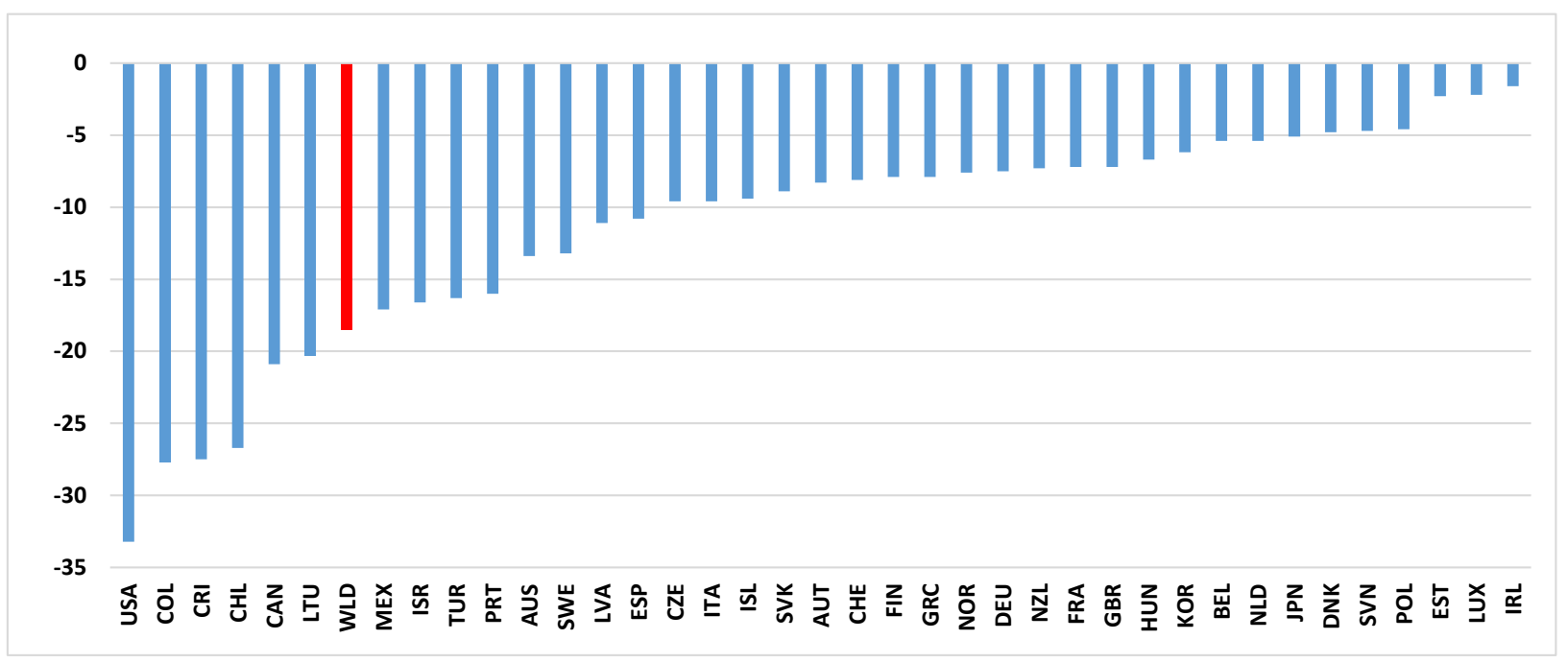

Note: World Travel and Tourism Council database

\subsection{Airline industry}

8. The airline industry is particularly exposed to international travel restrictions and falling confidence amongst travellers (International Transport Forum, 2020). Recent estimates of the International Civil Aviation Organisation (ICAO, 2020) on the COVID-19 impact on civil aviation indicate a reduction of 1,400 million international airline passengers for the whole of 2020 , about $75 \%$ lower than the previous year, while seat capacity contracted by an average of $66 \%$ (Figure 3, Panel A). International air passenger traffic, measured in industry-wide revenue passenger kilometres (RPKs), has been around $90 \%$ or more lower compared to the previous year since April (Figure 3, Panel B). There has been some recovery in domestic RPKs, but they were still down by over $40 \%$ year-on-year in November (IATA, 2020a). The International Air Transport Association (IATA) estimates a decline in global revenues of the airline industry by two-thirds in 2020 , with total employment declining by $36 \%$ to 1.9 million (IATA, 2020b). While wages and the industry fuel bill have declined, the total cost of infrastructure will fall much less than passenger volumes so leading to a further squeeze on airline profits. The recovery of the sector in Europe is forecast to be more hesitant than elsewhere due to a slower economic recovery, the greater importance of international services and because intra-regional travel in Europe has stalled as further waves of the virus have led to renewed travel restrictions. The duration, as well as the scale, of the shock poses particular risks for the aviation sector, which has a large proportion of highly-skilled technical jobs, highlighting the risks of an extended downturn that leads to substantial staff separations. 
Figure 3. The recovery in air travel is stalling after a complete collapse

A. Change in global airline international passengers kilometres and seat capacity, compared to 2019
B. Percentage change in revenue passenger, compared to 2019
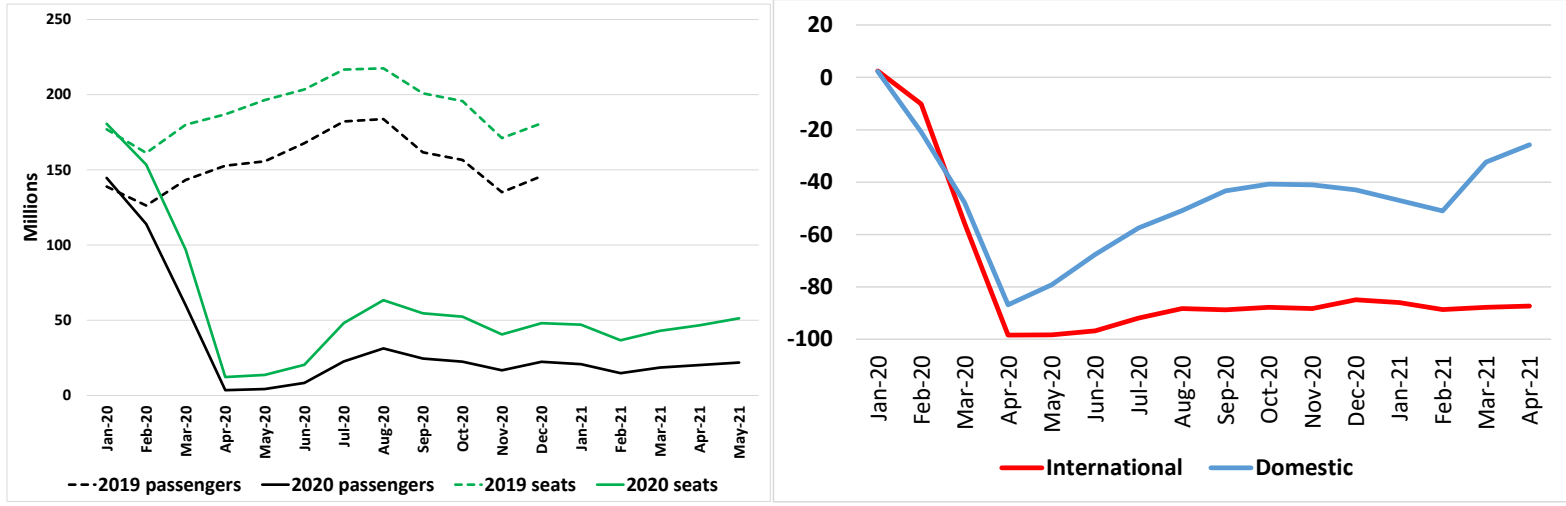

Source: IATA; ICAO.

\subsection{Other transport sectors}

9. Other transport sectors have been impacted by the crisis (OECD 2020a) and in particular, those largely connected to the tourism sector like the cruise industry.

10. The cruise industry has been especially heavily hit by the COVID-19 crisis with a loss of 25 million passengers in 2020, compared to pre-COVID expectations of 32 million passengers (Figure 4). Cruise Lines International Association (CLIA) estimates the worldwide impact on cruising between March and September 2020 will be a loss of USD 77 billion in economic activity, 518000 jobs and USD 23 billion in wages. The largest market is located in the United States with more than a half of annual customers and in Europe with one quarter of the global passenger volume. CLIA estimates that each day of suspension in the industry activity resulted in a loss of 600 jobs in the United States and 800 in Europe (CLIA, 2020).

Figure 4. Cruise operations have collapsed

Worldwide ocean cruise passengers carried

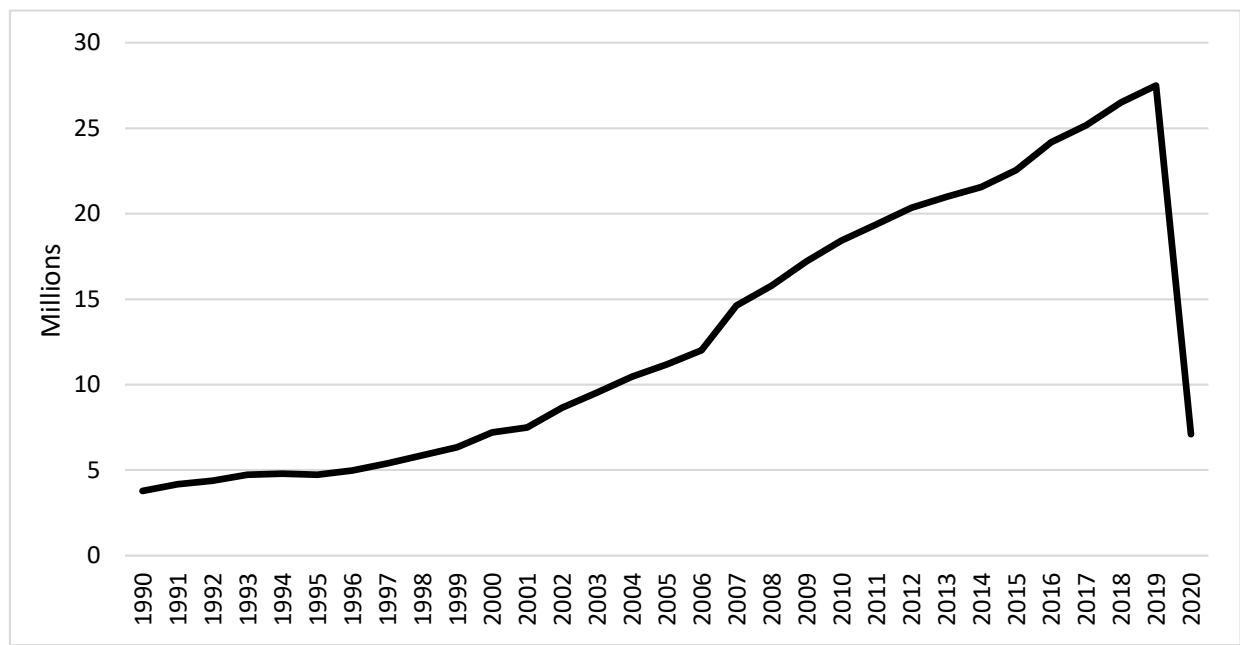

Source: Cruise Market Watch. 
11. International rail passenger volumes, which are particularly important in Europe, have collapsed for all operators. In 2020, the drop in international passengers was about $90 \%$ for cross-border train services in EU and EFTA countries (Community of European Railway and Infrastructure Companies, 2021). For example, from a peak of running more than 60 cross-border trains a day, Eurostar cut service to one daily round-trip between London and Paris, and one on its London-Brussels and Amsterdam routes. Passenger numbers have plunged 95 percent since March 2020. The company Thalys International, which normally carries 7 million passengers per year across French, Belgian, German and Dutch borders, reported a drop of $80 \%$ customers in 2020 and revenue losses of EUR 300 million. In March 2021, Deutsche Bahn Group indicated a fall by $50 \%$ in the overall volume of long-distance international passengers, from around 18 million in 2019 to only around 9 million in 2020, amounting to more than EUR 2 billion losses on long-distance operations for 2020 .

12. International tourism is a major component of demand in the car rental market, and its collapse has contributed to a decline in the global car rental market of about one-third in 2020. It was possibly the most important factor triggering one of the major global car rental companies, Hertz, to file for bankruptcy in the United States in May 2020.

\subsection{Further education}

13. In normal times, foreign students account for nearly $10 \%$ of tertiary education students in the median OECD country, but with a much higher share in Australia (around one quarter), Austria, New Zealand, Switzerland and the United Kingdom (all nearly one-fifth) (OECD, 2020b). Restrictions on international mobility, together with the closure of in-person learning, have led to a severe cutback in the number of international students. Many OECD countries decided not to admit international students for the academic year 2020/2021 if their courses were entirely on-line. In higher education, some institutions are facing a potential drop in international student enrolment of $50 \%$ to $75 \%$ (WTO, 2020). According to data from a snapshot survey designed by the Institute of International Education (IIE) to understand the impact of the COVID-19 pandemic on US higher education, total international student enrolments in US universities declined by $16 \%$ in autumn 2020 , while new international student enrolments dropped by 43\% (IIE, 2020). Recent estimates (Robinson et al., 2020), taking into account direct and indirect expenditures of foreign students in the United States, suggest they contribute to 752000 US jobs and that the absence of foreign students would cause US GDP to fall by USD 68 billion (about $0.3 \%$ of GDP).

\subsection{Labour migration}

14. Before the COVID-19 pandemic, international migrants, who made up $3.5 \%$ of the world's population in 2019, contributed nearly 10\% of global GDP (International Organization for Migration (IMO), 2020). More than $90 \%$ of the world's cross-border migrants moves voluntarily, usually for economic reasons, contributing 40 to $80 \%$ of labour force growth in major destination countries. The most recent estimates of the International Labour Organization (ILO) indicate that there are 164 millions of migrant workers around the world, of which 68\% reside in high-income countries (ILO, 2018)

15. Overall, in OECD countries, issuances of new visa/permits plummeted by $46 \%$ in the first semester of 2020 compared to the same period in 2019 and even more sharply in the second semester, with a decline by $72 \%$ (OECD, 2020b). ${ }^{3}$ Border closures and national lockdowns posed critical issues to the recuitment of temporary migrant workers, notably seasonal workers and health professionals, which the COVID-19 crisis has revealed as playing a critical role across OECD societies. On average, $13 \%$ of workers in occupations that have been identified as essential in the response to the pandemic in the EU (i.e. key workers) are immigrants (Fasani and Mazza, 2020). In the United States, $73 \%$ of the agricultural labour force is represented by immigrants, while $28 \%$ of highly-skilled healthcare professionals and $24 \%$

\footnotetext{
${ }^{3}$ The number of issuances of new visa/permits includes temporary (mostly temporary workers and students) as well as longer-term permits.
} 
of care workers and home health aides are foreign-born (U.S. Census Bureau; Batalova, 2020). Despite exceptional measures taken by some OECD countries (e.g. Australia, Canada, the United States or few European countries) to extend the stay of seasonal workers already present and to allow specific categories of migrants workers otherwise prohibited, ultimately many of them could not travel due to exit bans imposed by their origin countries.

16. The economic downturn caused by the COVID-19 pandemic combined to movement restrictions and income losses has also had a considerable impact not only on migrant workers at destination, but also on their families in home countries through reduced remittance flows. According to the latest estimates published by the World Bank, global remittances of migrant workers are projected to decline $14 \%$ by 2021 compared to the pre COVID-19 levels in 2019 (World Bank, 2020). The declines in 2020 and 2021 will affect all regions, with the steepest drop expected in Europe and Central Asia (by 16\%and 8\%, respectively).

\section{Broader macroeconomic impacts}

17. Identifying the overall macroeconomic effect of restrictions on international mobility is difficult given the extent and range of containment policies (including workplace and school closures, stay-at-home requirements, etc.) that have simultaneously been adopted by many countries since the start of the pandemic. However, the much stronger recovery in goods trade than services trade is strongly suggestive that restrictions on international mobility have had, and continue to have, a large and specific effect on services trade over and above more generalised effects from subdued demand: a proxy measure for the value of global goods trade in April 2021 was up nearly $15 \%$ on the same month of 2019 , whereas the corresponding measure of services trade was still down nearly $8.5 \%$ on two years earlier. ${ }^{4}$ Moreover, the decline in service exports experienced by particular countries is strongly correlated with their exposure to travel and tourism (Figure 5, panel A).

18. The halt in travel and tourism is having a knock-on impact on the wider economy, given the interlinked nature of the sector. The OECD estimates that more than a third of the tourism value added generated in the domestic economy comes from indirect impacts, reflecting the breadth and depth of linkages between tourism and other sectors (OECD, 2020c). The importance of these linkages is borne out by the fact that those OECD countries with the largest travel and tourism sectors -- such as Greece, Iceland, Portugal, Mexico and Spain -- are among those that have experienced the largest falls in GDP in 2020 (Figure 5, Panel B). Indeed, the pre-crisis size of the travel and tourism sector better explains crosscountry differences to actual GDP growth in 2020 , than exposure to any of the other sectors considered most vulnerable to COVID-19, or the average stringency of wider country lockdown measures during $2020 .{ }^{5}$ After controlling for other containment measures, a 10 percentage points of GDP greater exposure to the travel and tourism sector translates into a nearly 3 percentage points larger reduction in GDP in $2020 .^{6}$

\footnotetext{
4 This calculation is based on aggregating data from the World Trade Organisation on monthly nominal exports (denominated in dollars) across a subset of 39 countries, which normally cover three-quarters of world trade.

${ }^{5}$ Among OECD countries, the negative correlation between the GDP share of travel and tourism in 2019 and the projected percentage fall in total GDP in 2020 is 0.42 as shown in Figure 5 . This is higher than the correlation of projected 2020 GDP growth with the share of GDP accounted for by other service sectors considered to be most vulnerable to COVID (OECD, 2020d), including: retail and wholesale trade (correlation -0.32), real estate and business activities (correlation -0.13), arts and entertainment (correlation -0.09). It is also higher than the negative correlation of -0.36 with the average stringency of overall lockdown measures during 2020 as measured by the index constructed by the Blavatnik School of Government at Oxford University (Hale et al, 2020).

6 This slope coefficient is derived from a regression of GDP growth in 2020 for all OECD countries on the share of travel and tourism in GDP in 2019. The slope coefficient is very robust to the inclusion of other explanatory variables
} 
Figure 5. OECD countries most exposed to travel and tourism suffered greater falls in services exports and GDP

A. Real services exports growth in 2020

\section{Share of GDP generated by Travel \& Tourism in 2019 (\%)}

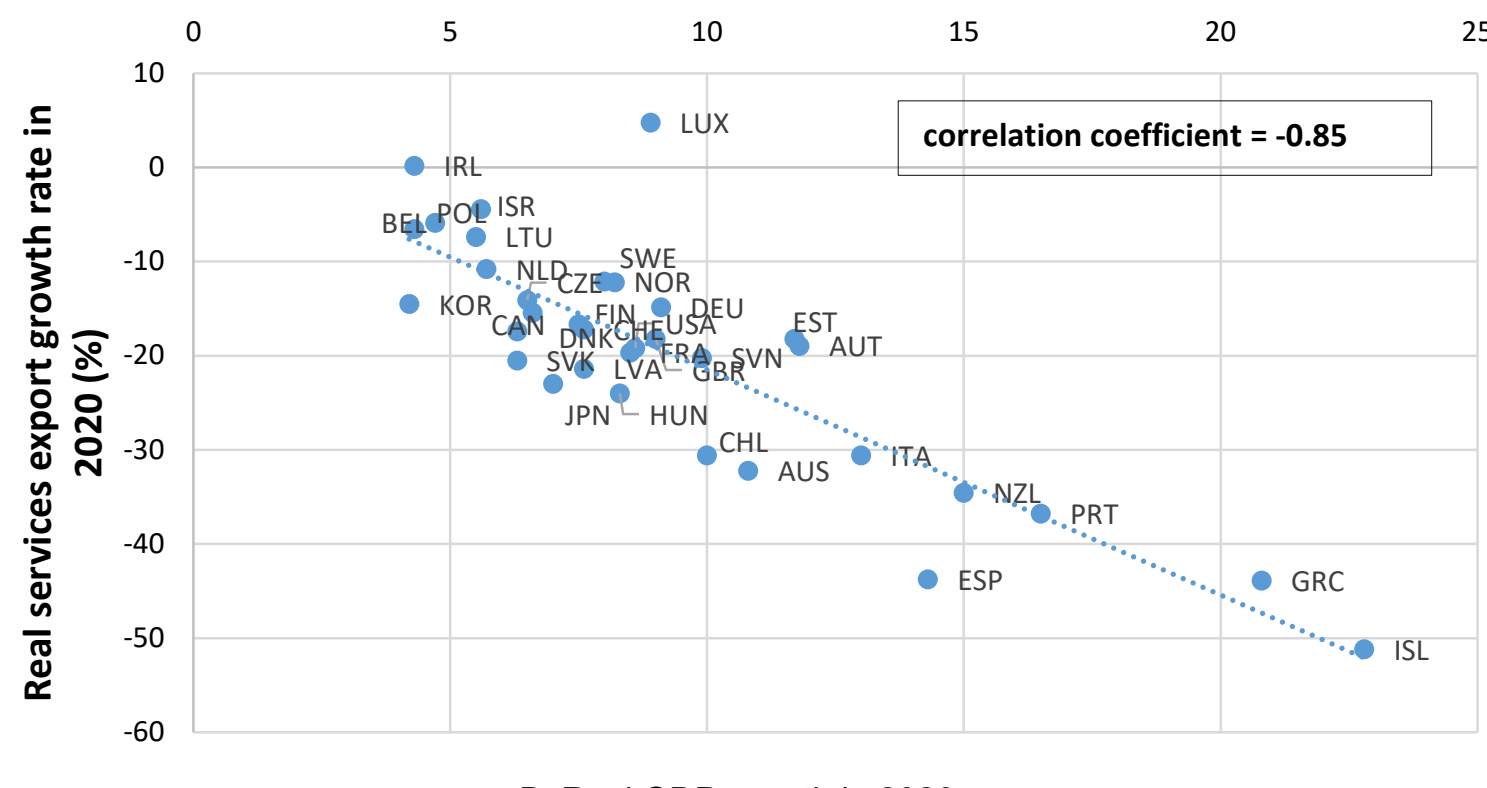

B. Real GDP growth in 2020

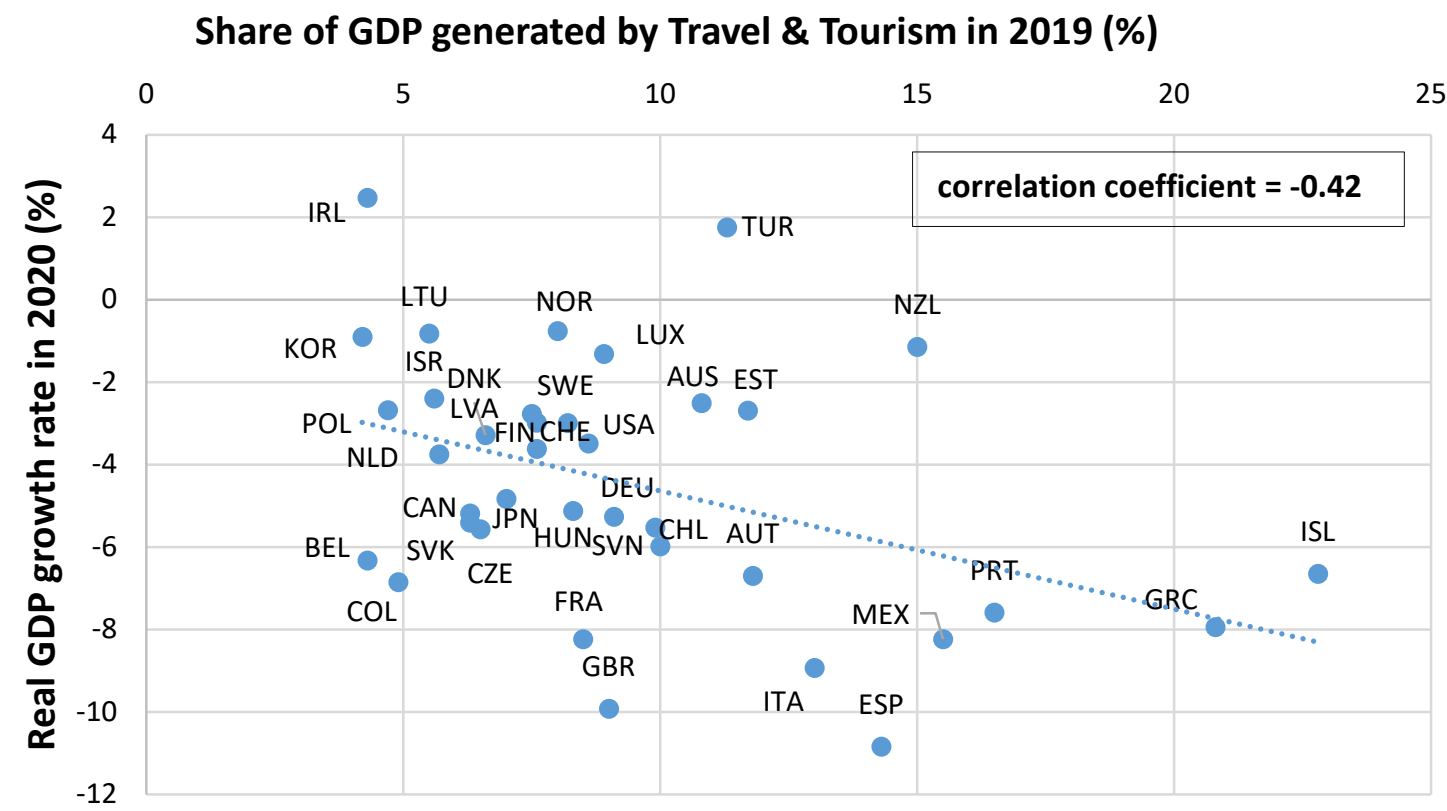

Note: For panel A, annual statistics of real trade in services for 2020 are not available for Mexico, Colombia and Turkey.

Source: OECD Economic Outlook database and World Travel \& Tourism Council database.

in the regression, including lagged GDP growth and the average stringency of all containment measures (which also reduce growth). 
19. The importance of indirect losses due to inter-sectoral linkages in the tourism industry is also emphasised by the United Nations Conference on Trade and Development (UNCTAD), which estimates losses in GDP to be approximately two to three times higher than the immediate loss in international tourist revenue (UNCTAD, 2020). By restricting international movement of people, travel bans have a broader impact than their direct effect on tourism and also increase the delivery cost in all services sectors. In a hypothetical scenario where all the countries are assumed to close their borders to passengers, but leave freight trade open, the OECD estimates that trade costs will rise by an average $12 \%$ in the medium term, of which $60 \%$ results from measures that restrict the movement of business travellers (OECD, 2021b).

20. The most recent estimates of the World Travel and Tourism Council reveal the massive loss of USD 4.5 trillion revenues borne by the global tourism industry in 2020, with its contribution to world GDP contracting by almost half, which compares to the total global economy dropping by only $3.7 \%$ last year (WTCC, 2021). The majority of losses during 2020 represent the struggles of the sector to cope with travel restrictions and quarantine requirements. Half of OECD countries, representing almost a quarter of global international tourism receipts, reported more than $50 \%$ contraction in travel and tourism GDP in 2020 (Figure 6).

\section{Figure 6. OECD countries suffered a large contraction in travel and tourism GDP}

Percentage change in total travel and tourism real GDP in 2020 compared to 2019

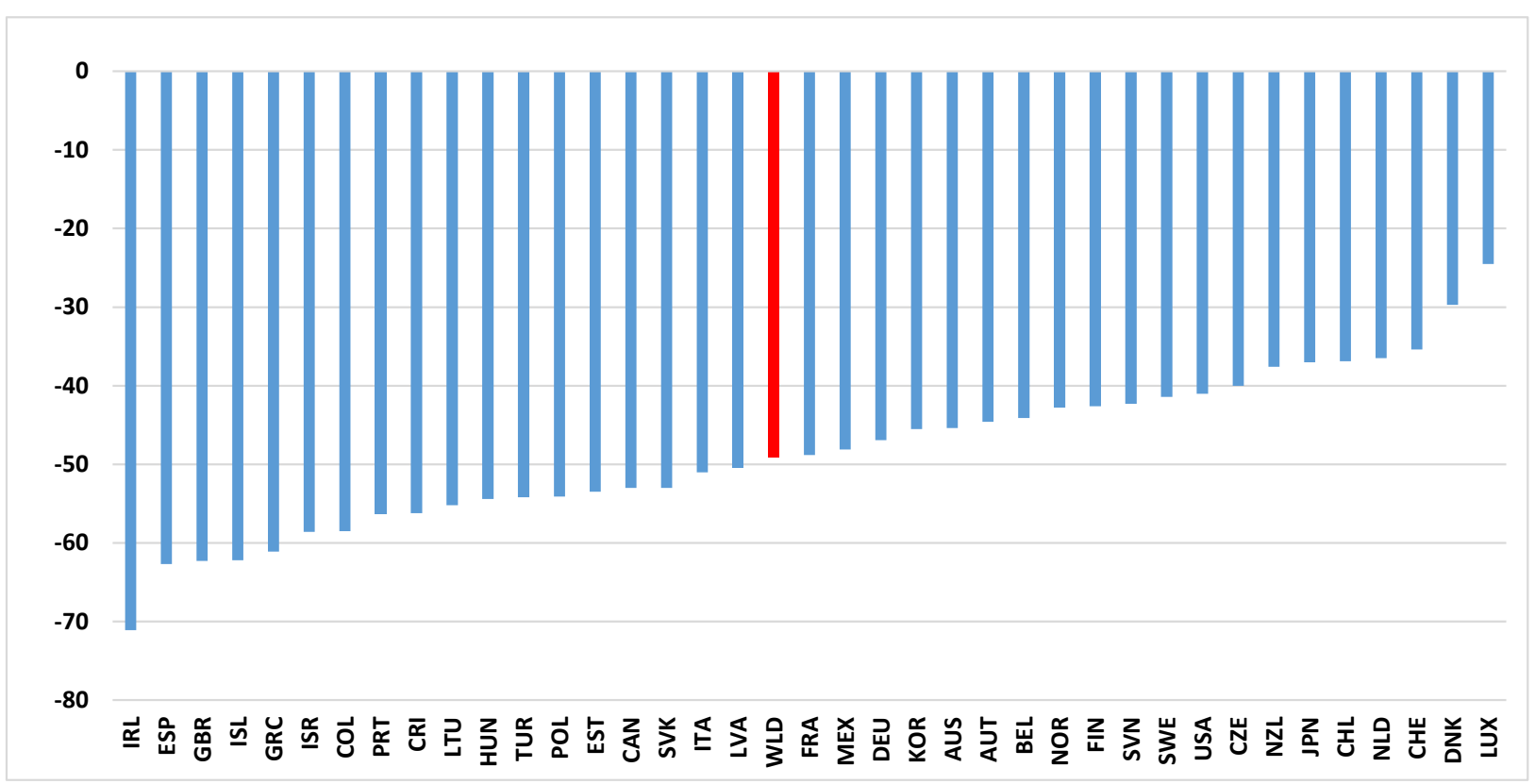

Source: World Travel \& Tourism Council database.

21. Looking ahead, most experts of the tourism industry do not to see a return to pre-pandemic levels happening before 2023. Due to the travelling restrictions still in place, also the airline industry body IATA expects full-year 2021 passenger numbers to be just $52 \%$ of pre-COVID levels, rising to $88 \%$ in 2022 , and exceeding 2019 levels only in 2023 (IATA, 2021). For the association, the airline industry's crisis is no longer being caused by the health situation, but by the restrictions to international mobility still holding back cross-border travelling. According to a survey carried out in January 2021 by the United Nations World Tourism Organisation (UNWTO) among professionals, "it will take two and a half to four years for international tourism to return to 2019 levels" (UNWTO, 2021). Consistent with the UNWTO projections, the United Nations Conference on Trade and Development (UNCTAD) published a report assessing the 
14 | ECO/WKP(2021)29

economic consequences of a protracted COVID-19 crisis on global tourism, taking into account backward linkages in the tourism sector as well as the asymmetric roll-out of vaccinations (UNCTAD, 2021). According to the three scenarios drawn, a loss in world real GDP of between USD 1.7 trillion and USD 2.4 trillion is expected for 2021. Output losses are worse than previously projected, as even the worst-case scenario UNCTAD projected last year has turned out to be optimistic, with international travel at a 15month stand-still since the pandemic started (UNCTAD, 2020). 


\section{References}

Batalova Jeanne (2020), "Immigrants health-care workers in the United States", Migration Information Source, May 2020,

CER (2021), "2020 figures reveal $€ 26$ billion loss for railways due to COVID-19", January 2021.

CLIA (2020), "2021 State of the Cruise Industry Outlook", September 2020.

European Commission Joint Research Centre (2020), "Behavioural changes in tourism in times of Covid19: Employment scenarios and policy options", JRC Science for Policy Report.

Fasani F. and J. Mazza (2020), "Immigrant Key Workers: Their Contribution to Europe's COVID-19 Response", IZA Policy Papers 155.

Hale et al, 2020, Oxford COVID-19 Government Response Tracker", Blavatnik School of Government, Oxford University.

IATA (2020a), "Air Passenger Market Analysis", November 2020.

IATA (2020b), "2020 End-year Report”, November 2020.

IATA (2021), "COVID-19: An almost full recovery of air travel in prospect", May 2021.

ICAO (2020), "Effects of Novel Coronavirus (COVID-19) on Civil Aviation: Economic Impact Analy sis", International Civil Aviation Organization, Air Transport Bureau, Montreal, December 2020.

IIE (2020), “Fall 2020 International Student Enrolment Snapshot”, November 2020.

ILO (2018), "Global estimates on international migrant workers : results and methodology", Geneva : ILO, 2018.

ILO (2020), “The impact of COVID-19 on the tourism sector" Briefing Note, June 2020.

IMO (2020), "Why migration matters for "recovering better" from Covid", Issue Brief, June 2020.

ITF (2020), "Restoring air connectivity under policies to mitigate climate change", COVID-19 TRANSPORT BRIEF, International Transport Forum, May.

OECD (2021a), "OECD Initiative for Safe International Mobility during the COVID-19 Pandemic (including revised Blueprint)", DELSA/HEA(2021)1.

OECD (2021b), "COVID-19, international mobility and trade in services: The road to recovery", Tackling Coronavirus Series, OECD Publishing, Paris

OECD (2020a), "Mitigating the impact of COVID-19 on tourism and supporting recovery", OECD Tourism Papers, 2020/03, OECD Publishing, Paris.

OECD (2020b), “International Migration Outlook 2020", OECD Publishing, Paris.

OECD (2020c), "Rebuilding tourism for the future: COVID-19 policy responses and recovery", Tackling Coronavirus Series, OECD Publishing, Paris.

OECD (2020d), "Evaluating the Initial Impact of COVID-19 Containment Measures on Economic Activity", Tackling Coronavirus Series, OECD Publishing, Paris. 
Robinson S., M. Noland, E. Gornostay and S. Han (2020), "The Short- and Long-Term Costs to the United States of the Trump Administration's Attempt to Deport Foreign Students", Peterson Institute for International Economics Working Paper 20-11.

UNCTAD (2020), "Covid-19 and Tourism: Assessing the Economic Consequences" (UNCTAD/DITC/INF/2020/3), 2 July 2020.

UNCTAD (2021), “Covid-19 and Tourism: An update", 30 June 2021.

UNWTO (2020), “World Tourism Barometer”, Volume 18, Issue 7, December 2020.

UNWTO (2021), "UNWTO Panel of Tourism Experts", May 2021.

U.S. Travel Association (2021), "Fact Sheet: Travel's Dramatic Losses in 2020", June 2021.

WTO (2020), "Cross-border mobility, COVID-19 and global trade", Covid-19 Reports, No. 2020/12, WTO, Geneva.

World Bank (2020), "COVID-19: Remittance Flows to Shrink 14\% by 2021", Press Release, October 2020.

World Travel and Tourism Council (2021), "Economic Impact Report (EIR 2021)”, March 2021. 